\title{
Nephroprotective Effect of Pterocarpus indicus Willd. Leaves : Observation of Urine Volume, Sodium and Potassium Levels in Gentamicin-induced Rat Model
}

\author{
Fadlina Chany Saputri', Zahra Adiyati', Desy Rasta Waty² \\ 'Laboratory of Pharmacology, Faculty of Pharmacy, Universitas Indonesia, Depok, 16424, INDONESIA. \\ 2Laboratory of Phytochemistry, Faculty of Pharmacy, Universitas Indonesia, Depok, 16424, INDONESIA.
}

\begin{abstract}
Introduction: Kidney disease is a common disease worldwide. The leaves from Pterocarpus indicus Willd. is alternatively applied for prevention therapy of patients with kidney diseases. Objective: The aim of this study to demonstrate the scientific nephroprotective effect of water-boiled $P$. indicus leaves evaluated from urine volume, sodium and potassium levels. Materials and Methods: Thirty male Sprague-Dawley rats were divided into five treatment groups; group I (control), group II (gentamicin-induced $80 \mathrm{mg} / \mathrm{kg}$ i.p from day 15 to 21 ), and group III to V (induced; variated doses respectively $28.8 \mathrm{mg} / \mathrm{kg} ; 57,6 \mathrm{mg} / \mathrm{kg}$; and $115,2 \mathrm{mg} / \mathrm{kg}$ bw which was given for 21 days orally as single doses). Nephroprotective effects were observed as abnormal from levels of urinary volume. Results: Obtained results on sodium and potassium levels show the group given the highest dose $(115,2 \mathrm{mg} / \mathrm{kg})$ resulted in decreased sodium levels and increased levels of urinary potassium as well as having a significant difference $(p<0,05)$ to the induction group. Observed 24-hour urine volume, however, did not show any significant signs of nephroprotective effects. Conclusion: It can
\end{abstract}

be concluded that the leaves of P.indicus have potential nephroprotective properties.

Key words: Pterocarpus indicus, Gentamicin, Potassium, Sodium, Urine volume, Nephroprotective.

Correspondence :

Fadlina Chany Saputri

Laboratory of Pharmacology, Faculty of Pharmacy, Universitas Indonesia,

Depok, 16424, INDONESIA.

Tel: +62217270031

Email: fadlina.chany@farmasi.ui.ac.id

DOI: 10.5530/jyp.2017.1s.21

\section{INTRODUCTION}

The kidney is one of the major target organs suffered from toxic substances other than the liver. This is caused partly because the kidney is the main route for excretion of toxic substances (e.g. reactive oxygen species, etc.). In addition, the kidneys have a vast volume of blood flow to concentrate the toxic substances in the filtrate, bringing the toxic substances through the tubular cells and potentially activate specific toxic substances. ${ }^{1}$ Kidneys remove toxic substances from the body through glomerular filtration, tubular diffusion, and tubular secretion mechanisms. Glomerular capillaries have large pores, causing most of the toxic substances being able to pass through the glomerulus and experience passive absorption in tubular cells, and resulting in every part of the nephron marred by potentially nephrotoxic agents. ${ }^{2}$

One cause of renal dysfunction is the induction of drugs with nephrotoxic side effects, such as aminoglycoside antibiotics, tenofovir, amphotericin B, cisplatin, carboplatin, cyclosporine. ${ }^{3}$ Gentamicin is an aminoglycoside antibiotic known to have ototoxicity and nephrotoxicity as side effects. Gentamicin toxicity is a result of the accumulation and retention of aminoglycosides in proximal tubular cells. ${ }^{4}$ Other factors that cause renal toxicity is the increase of reactive oxygen species (ROS), which can induce oxidative stress in the kidney. Currently, the use of gentamicin as nephrotoxic agents conducted in animals and humans is commonly applied in studies. ${ }^{5}$

Gentamicin can cause tubular necrosis and increase free radicals in the kidneys, resulting in kidney damage characterized by increased plasma urea and creatinine, albuminuria, decreased glomerular filtration rate
(GFR), and renal dysfunction. ${ }^{6}$ Clinically reduced GFR is proportional to the volume of urine produced; decrease in urine volume can reach to $400 \mathrm{~mL}$ in humans on gentamicin-induced nephrotoxicity. ${ }^{5,7}$ Necrosis of tubular reabsorption mechanisms causes dysfunction and tubular secretion, resulting in a change of the content of electrolytes such as sodium and potassium in the urine. ${ }^{8}$ Therefore, the observation of urine volume and sodium and potassium in the urine can be used as a parameter of renal damage.

Authentic medicine is widely used for prevention, diagnosis, and treatment of various diseases and has received public attention during the past 20 years as a kind of medication that is readily available in some areas. ${ }^{9}$ The skin of the roots and leaves of Pterocarpus indicus Willd., also known as "Angsana", have been used by most Indonesian people to treat kidney disease; yet the use of P.indicus leaves in the treatment of kidney diseases is not supported by scientific data. ${ }^{10}$

P.indicus leaves contains chemical compounds, e.g. (-)-epicatechin, isoflavones, flavones, narrin, santalin, pterocarpine, pterocarpol, $\beta$-eudesmol, etc. ${ }^{11,12}$ The flavonoid content is alleged for its role in the treatment of kidney disease. Flavonoids work as antioxidants and oxidize free radicals. They prevent renal oxidative stress by increasing glutathione (glutathione sulfhydryl or GSH), GSH synthesis induction, or scavenger effect on reactive oxygen species (ROS).$^{13}$ Flavonoids contained in P.indicus leaves may be capable of acting in the prevention of nephrotoxicity caused by an increase of ROS which contributes to the death of the nephrons in the kidney. 
A study on free radical activity in leaves of P.indicus shows that leaves which were extracted using decoction method with n-hexane and then with $70 \%$ ethanol resulted positive. Screening of free radical activity of P.indicus extract was done with DPPH (2,2-diphenyl-1-pycrilhidrazyl) and DPPH free radical binding ability was measured at a wavelength of $518 \mathrm{~nm}$ using a UV-Vis spectrophotometer. The results showed the hexane extract from the leaves of P.indicus had $\mathrm{IC}_{50}$ of $159 \mathrm{mg} / \mathrm{mL}$ and ethanol extracts of P.indicus leaves showed $\mathrm{IC}_{50}$ of $27.4 \mathrm{mg} / \mathrm{mL}$. $^{14}$ This shows that leaves from P.indicus have potential free radical scavenger activity. However, systematic and scientific reports on the investigation of P.indicus for its effects on renal function are scarce. Therefore, the kidney-protective activity of P.indicus leaves in gentamicin-induced rats in terms of urine volume, sodium and potassium levels was investigated.

\section{MATERIALS AND METHODS}

\section{Plant materials}

Fresh leaves were found and collected from Majalengka, West Java, Indonesia and were identified by the Research Center for Biology, Indonesian Institute of Sciences (LIPI), Cibinong, Bogor, Indonesia, with the determination specimen number 13-407/IPH.3./KS/II/2016.

\section{Preparation of plant materials}

P.indicus leaves were rinsed with running water. The leaves were then carefully weighed 2.9 grams, an equivalent of 3-4 leaves. Fresh leaves were further boiled with $500 \mathrm{~mL}$ of distilled water using a low heat until reaching $100^{\circ} \mathrm{C}$ and acquired half the initial volume of $250 \mathrm{~mL}$. Test solutions were made fresh every day for treatment of test animals.

\section{Animal Study}

White male Sprague-Dawley rats that were used in this experiment were obtained from the Bogor Agricultural Institute (IPB), weighing 150200 grams, 8 weeks of age as much as 30 individuals. Before treatment, the animals were acclimatized for 14 days in standard animal cages to adapt at standard condition temperature $\left(25 \pm 20^{\circ} \mathrm{C}\right)$ and light $(12 \mathrm{~h} \mathrm{light} /$ dark cycles). During the acclimatization conducted, observation of the general state of test rats and weighing was done every day. Permission and approval for animal studies were obtained from ethics committee in Faculty of Medicine, Universitas Indonesia (Approval No. 236/UN2.F1/ ETIK/2016).

\section{Acute renal injury-induction method}

Induced nephrotoxicity determination was made based on the results of research that were conducted. Induction was performed using gentamicin (GM) at a dose of $80 \mathrm{mg} / \mathrm{kg}$ bw given for 7 days showed that gentamicin dose in a period and has been able to cause kidney damage characterized by elevated plasma creatinine levels.

\section{Dosage and Treatment Duration}

Selection of dose and duration of treatment provision is based on the results of previous studies that used the provision of water-boiled P.indicus leaves at the dose $11.52 \mathrm{mg} / 200 \mathrm{~g}$ bw orally for 21 days. P.indicus leaf decoction dose of $11.52 \mathrm{mg} / 200 \mathrm{~g}$ bw was set to be dose II. Dose I is half of dose II and dose III is twice of dose II. Doses used in the main study are respectively $5.76 \mathrm{mg} /$ head, $11.52 \mathrm{mg} /$ head and $23.04 \mathrm{mg} /$ head and duration of P.indicus administration is 21 days.

\section{Animal grouping and treatment}

The research was conducted using 30 male rats that were weighed and randomly divided into five treatment group of 6 rats and treated as follows (Table 1): Group I (control) were administered distilled water. Group II as the GM-induced group was administered distilled water from day 1 to day 14 and gentamicin intraperitoneally from day 15 to day 21. Group III, $\mathrm{IV}$, and $\mathrm{V}$ were respectively administered the test preparation in the form of water solutions of P.indicus leaves with graded doses respectively 5.76, 11.52 , and $23.04 \mathrm{mg} / 200 \mathrm{~g}$ bw. Group III, IV, V were given the test preparation for 21 days and were given gentamicin intraperitoneally on day 15 to day 21 . On day 22 , test animals were put in metabolic cages and cumulative 24-hour urine collection was conducted in all groups for observation of urine volume, urinary sodium, and potassium levels.

\section{Urine Examination}

At the end of the $22^{\text {nd }}$ day, test animals which fasted overnight were weighed, given water, followed by group treatment. During the experiment, the test animals were placed in metabolic cages for up to $24 \mathrm{hs}$ after administration of the treatment. Urine was collected in falcon tubes that were given $0.5 \mathrm{ml}$ of toluene (Merck, Germany). After urine collection, each tube containing urine from each treatment group was observed based on the volume and compared quantitatively. Measurement of sodium and potassium levels were analyzed by atomic absorption spectrophotometry. Collected urine was taken as much as $0.5 \mathrm{~g}$ and placed in Erlenmeyer flasks before adding $2 \mathrm{~mL} \mathrm{HNO}_{3}$ (Merck, Germany). The solution was then sonicated for $30 \mathrm{~min}$ and filtered with filter paper. Measurements were conducted using atomic absorption spectrophotometer Shimadzu AA-6300 Japan, at a wavelength of $589.0 \mathrm{~nm}$ for sodium and $766.7 \mathrm{~nm}$ for potassium.

\section{Statistical Analysis}

All values were represented as mean \pm standard deviation (SD). Data obtained from this work were analyzed statistically using SPSS. Analysis conducted were homogeneity (Levene test) and test of the normal distribution (Shapiro-Wilk test). To see the relationship between the treatment groups, one-way analysis of variance (ANOVA) was conducted followed by an analysis of Significant Difference test (LSD). Differences between means will be considered significant at $5 \%$ level of significance i.e $P<0.05$.

\section{RESULTS}

\section{Urine Volume Examination}

Observations of 24-h urine volume (Table 2) show that the urine volume average after 21 days of treatment in each group shows no significant difference between the control group with the other treatment groups, based on a one-way ANOVA ( $\alpha=0.05)$ on a 24 -h urine volume data.

\section{Sodium and Potassium Assay on 24-h Urine}

The measurement results of urine sodium and potassium levels on average within $24 \mathrm{~h}$ after 21 treatment days can be seen in Table 3. Based on the one-way ANOVA $(\alpha=0.05)$ on urine sodium levels, it was found that there was a significant difference of sodium levels between the induced group and dose III group. Based on a one-way ANOVA $(\alpha=0.05)$ on levels of potassium in the 24 -h urine, it was found that there was a significant difference of potassium levels between the induced group and dose group III.

\section{DISCUSSION}

The most common limitation of gentamicin is nephrotoxicity. Acute kidney injury is highly possible in human as well as animal subjects overdosing of gentamicin. Gentamicin's intracellular metabolism induces the formation of toxic reactive metabolites into free radicals. Hydroxyl radicals formed during oxidation lead to lipid peroxidation, causing oxidative deterioration, structure and function modification of polyun- 
saturated lipid in membranes. These reactive metabolites suppresses the concentration of antioxidants, superoxide dismutase, glutathione, catalase, and other factors that contributes to tissue protection and removes reactive oxygen species., ${ }^{5-17}$

Criteria of acute renal failure severity according to the AKIN (Acute Kidney Injury Network) suggested urine output as one of the criteria observations for acute renal failure. ${ }^{7,18}$ Urine output may decrease gradually $0.5 \mathrm{~mL} / \mathrm{kg} / \mathrm{hr}$ for 6-12 hours for AKI. ${ }^{7}$ Therefore, observations on urine volume in group II (GM) should indicate lower urine volume to group I (normal). Results of 24-h urine volume measurements indicate that treatment groups given P.indicus leaves at three varied doses did not approach similarity with the control group, but experienced a trend of increasing urine volume proportional to the increase in dose. Moreover, the observation on 24-h urine volume showed that the mean urine volume in the induction group resulted higher than the control group. The results do not describe kidney damage based on the criteria of damage by AKIN which should have tended to oliguria or anuria. Unstable ROS and TGF activity may be several factors causing results unexpectedly different to AKIN parameters. In addition, the presence of different tubular and glomerular mechanisms that contribute to the GFR result in an insignificant water expenditure, even with the presence of TGF response. Various nephrotoxicity studies using aminoglycosides show urine output in early stages of acute renal failure is non-oliguria or polyuria, but creatinine and urea accumulation in the blood can still be detected. ${ }^{5,7,19}$ In addition, many factors affecting urine volume may cause insignificant results in showing presence or absence of nephrotoxicity in kidneys. One study conducted by Portella et al. favor the occurrence of polyuria in the gentamicin-induced group. The study describes the provision of Echinodorus macrophyllus on urine elimination, in a dose-dependent induction group with gentamicin, presented polyuria and decreased GFR. ${ }^{19}$ Therefore, observation of urine volume did not significantly describe tubule damage in the kidney, thus not able to describe expected effects for nephrotoxicity.

Internal environment regulation of body cells is primarily maintained by the kidney through glomerular filtration, reabsorption and emission by tubules, and also hydrogen particle exchange. In normal situations, most of the substances such as urea, creatinine, protein, electrolytes and glucose are reabsorbed by the tubules within normal concentrations. Those substances appear in the urine if plasma level exceeds or when renal tubules defects, possibly resulting in nephrotoxicity. ${ }^{20}$ Thus, urine sodium and potassium levels can predict its correlation as demonstrated in the present study. Measurements for 24-h urinary sodium in group V presented low concentration of urinary sodium. In absolute terms, the average level of 24-h urinary sodium under normal conditions is 54.3 to $81.0 \mathrm{mEq} / \mathrm{L}$ in male Sprague-Dawley rats. ${ }^{21}$ Observation on mean sodium content suggested that very low levels were obtained due to sodium being a compound that is actively reabsorbed back into peritubular capillaries caused by the different gradients which are formed when water is reabsorbed in the proximal tubules and collecting ducts that may affect sodium levels excreted into the urine, resulting in low urine sodium levels.

Under normal conditions, the average number for potassium in 24-h urine samples on male Sprague-Dawley rats is 168.0 to $292.7 \mathrm{mEq} / \mathrm{L}^{21}$ Results of the study suggested that mean potassium levels in the group I, group IV and group V were still within the normal range, whereas the group II and group III were below the normal range. This gives an illustration that increasing the dose of P.indicus leaves is directly proportional to the increase in urinary potassium levels close to normal.

Taken together the results on 24-h urinary sodium and potassium levels, group V presented a significant difference to group II. This is due to the induction of secondary metabolites of flavonoids, tannins contained in

\section{Table 1: Grouping and treatment of test animals}

\begin{tabular}{|c|c|c|}
\hline Group & $\begin{array}{c}\text { Number of } \\
\text { Rats }\end{array}$ & Treatment ( 21 days) \\
\hline I & 6 & aqua pro injection i.p. \\
\hline II & 6 & gentamicin (GM) (80 mg/kg bw, i.p. for 7 days) \\
\hline III & 6 & $\begin{array}{l}\text { water-boiled P.indicus leaves ( } 28.8 \mathrm{mg} / \mathrm{kg} \text { bw, } \\
\text { p.o. })+\mathrm{GM}(80 \mathrm{mg} / \mathrm{kg} \text { bw, i.p. for } 7 \text { days })\end{array}$ \\
\hline IV & 6 & $\begin{array}{l}\text { water-boiled P.indicus leaves ( } 57.6 \mathrm{mg} / \mathrm{kg} \text { bw, } \\
\text { p.o })+\mathrm{GM}(80 \mathrm{mg} / \mathrm{kg} \text { bw, i.p. for } 7 \text { days })\end{array}$ \\
\hline $\mathrm{V}$ & 6 & $\begin{array}{c}\text { water-boiled P.indicus leaves }(115.2 \mathrm{mg} / \mathrm{kg} \text { bw, } \\
\text { p.o })+\mathrm{GM}(80 \mathrm{mg} / \mathrm{kg} \text { bw, i.p. for } 7 \text { days })\end{array}$ \\
\hline
\end{tabular}

Abbreviatons: $\mathrm{p} . \mathrm{o}=$ per oral; i.p=intra peritoneal

Table 2: Average urine volume per treatment group

\begin{tabular}{cc}
\hline Group $(\mathrm{n}=6)$ & Mean Urine Volume $(\mathrm{mL}) \pm$ SD \\
\hline Control & $14.5 \pm 2.51^{\star}$ \\
GM-Induced & $19.2 \pm 3.36 \#$ \\
GM:Dose 1 & $18.2 \pm 2.40 \#$ \\
GM:Dose 2 & $18.3 \pm 2.89 \#$ \\
GM:Dose 3 & $19.4 \pm 2.60 \#$ \\
\hline
\end{tabular}

\# : Significantly different $(\mathrm{p} \leq 0,05)$ with control group;

*: Significantly different $(\mathrm{p} \leq 0,05)$ with induction group

Table 3: Sodium and potassium levels in the 24-hour urine

\begin{tabular}{ccc}
\hline Group $(\mathrm{n}=3)$ & $\begin{array}{c}\text { Mean Sodium Levels } \\
(\mathrm{mEq} / \mathrm{L}) \pm \mathrm{SD}\end{array}$ & $\begin{array}{c}\text { Mean Potassium Levels } \\
(\mathrm{mEq} / \mathrm{L}) \pm \mathrm{SD}\end{array}$ \\
\hline Control & $9.25 \pm 0.51^{*}$ & $241.97 \pm 2.50^{*}$ \\
GM-Induced & $24.54 \pm 8.56 \#$ & $96.09 \pm 14.27 \#$ \\
GM:Dose 1 & $25.33 \pm 1.96 \#$ & $159.71 \pm 22.27 \#^{*}$ \\
GM:Dose 2 & $18.49 \pm 1.62 \#$ & $195.16 \pm 13.28 \#^{*}$ \\
GM:Dose 3 & $12.28 \pm 2.03^{*}$ & $224.76 \pm 15.00^{*}$ \\
\hline
\end{tabular}

\# : Significantly different $(\mathrm{p} \leq 0,05)$ with control group;

*: Significantly different $(\mathrm{p} \leq 0,05)$ with GM-Induced group

water-boiled P.indicus leaves that play a role in counteracting free radicals that were caused by administration of gentamicin. Levels of sodium and potassium in group $\mathrm{V}$ were normal, resulting in no significant difference to the control group. No significant decrease in levels of sodium and increased potassium levels in group III and group IV were possibly due to the less amount of flavonoid and tannin on both doses, letting free radicals still causing renal tubular cell death. Another possible factor was the short administration duration of P.indicus samples.

\section{CONCLUSION}

Our study suggests that administered water-boiled P.indicus leaves at dose $115.2 \mathrm{mg} / \mathrm{kg}$ bw possesses potential nephroprotective effects on gentamicin-induced rat model in terms of decreased levels of sodium and increased potassium levels, showing similarity to control group and showed significant difference ( $\mathrm{p}<0.05$ ) with the induction group, but the observation of urine volume showed no significance for nephroprotective effect. 


\section{ACKNOWLEDGEMENT}

This research is supported by Faculty of Pharmacy, Universitas Indonesia and funded by Hibah PITTA Universitas Indonesia.

\section{CONFLICT OF INTEREST}

The authors report no conflict of interest.

\section{ABBREVIATION USED}

GFR: Glomerular filtration rate; GSH: Glutathione sulfhydryl; ROS: Reactive oxygen species; DPPH: 2,2-diphenyl-1-pycrilhidrazyl; GM: Gentamicin; SD: Standard deviation; AKIN: Acute kidney injury network; AKI: Acute kidney injury; TGF: Transforming growth factor .

\section{REFERENCES}

1. National Agency of Drug and Food Control. Uji keamanan sediaan jadi ekstrak kering daun jati belanda (Guazuma ulmifolia L.) terhadap fungsi dan histologis ginjal tikus jantan. Info POM. 2004;5(5):1-12.

2. Lu FC. Basic Toxicology: Fundamentals, Target Organs, and Risk Assesment. 4th ed. London: CRC Press; 2002.

3. Dipiro JT, Wells BG, Schwinghammer TL, Dipiro CV. Pharmacotherapy handbook. New York: McGraw-Hill; 2009.

4. Brunton L, Lazo J, Parker K. Goodman and Gilman The Pharmacological Basis of Therapeutics. $11^{\text {th }}$ ed. New York: McGraw-Hill; 2008.

5. Lopez-Novoa JM, Quiros Y, Vicente L, Morales Al, Lopez-Hernandez FJ. New insights into the mechanism of aminoglycoside nephrotoxicity: an integrative point of view. Kidney Int. 2010;79(1):33-45. Available from: http://dx.doi. org/10.1038/ki.2010.337

6. Balakumar P, Rohilla A, Thangathirupathi A. Gentamicin-induced nephrotoxicity Do we have a promising therapeutic approach to blunt it?. Pharmacol Res. 2010;62(3):179-86

7. Schrier RW. Manual of Nephrology. $8^{\text {th }}$ ed. Philadelphia: Wolters Kluwer Health.
2015;201-40.

8. Kumar V, Abbas AK, Aster JC. Robbins and Cotran Pathologic Basis of Disease. $8^{\text {th }}$ ed. Philadelphia: Elsevier; 2013.

9. Humber JM. The role of complementary and alternative medicine: accommodating pluralism. J Am Med Assoc. 2002;288(13):1655-6.

10. Utami P. Buku Pintar Tanaman Obat: 413 Jenis Tanaman Penggempur Aneka Penyakit. Jakarta: Agromedia Pustaka; 2008.

11. Takeuchi S, Kono Y, Nambata T, Hadiman NT, Watanabe R, Suzuki Y, et al. A Bioactive Polyphenolic Constituent in the Bark of Pterocarpus indicus, Willd and Its Effects on Animal Cell Phenotypes in vitro. Agric Biol Chem. 1986;50(5):1117-22

12. Duke JA. Pterocarpus indicus Willd. 1983. Available from : https://hort.purdue. edu/newcrop/duke_energy/Pterocarpus_indicus.html.

13. Dahal A, Mulukuri S. Flavonoids in kidney protection. World J Pharm Pharmaceut Sci. 2015;4(3):362-82.

14. Syukur R, Alam G, Mufidah, Rahim A, Tayeb R. Aktivitas Antiradikal Bebas Beberapa Ekstrak Tanaman Familia Fabaceae. JST Kesehat. 2011;1(1):61-7.

15. Varatharajan R, Jun LH, Kai TZ, Jian LW, Anburaj J, Vijayan V. Morphological and Morphometric Study of Edaravone in Gentamicin-Induced Nephrotoxicity in Sprague-Dawley Rats. J Young Pharm. 2017;9(1):31-5.

16. Mishra S, Pani SR, Sahoo S. Anti-nephrotoxic activity of some medicinal plants from tribal rich pockets of Odisha. Pharmacognosy Res. 2014;6(3):210-7.

17. Solomon JA, Ganeshpurkar A, Pandey V, Bansal D, Dubey N. Protective effect of Trichosanthes dioica extract against gentamicin induced nephrotoxicity in rats. Pharmacogn Commn. 2016;6(1):23-7.

18. Ricci Z, Cruz DN, Ronco C. Classification and staging of acute kidney injury : beyond the RIFLE and AKIN criteria. Nat Rev Nephrol. 2011;7(4):201-8.

19. Portella VG, Cosenza GP, Diniz LRL, Pacheco LF, Cassali GD, Caliari MV, et al. Nephroprotective effect of Echinodorus macrophyllus Micheli on gentamicininduced nephrotoxicity in rats. Nephron Extra. 2012;2(1):177-83.

20. Elsayed MGA, Elkomy AAA, Gaballah MS, Elbadawy M. Nephrotoxicity of cefepime: A new cephalosporin antibiotic in rats. J Pharmacol Pharmacother. 2014;5(1):33-8.

21. Powers WJ. Renal Toxicology: Renal Function Parameters for Adult Fischer-344 Sprague-Dawley, and Wistar Rats. In: Derelanko MJ, Hollinger MA, editors. Handbook of Toxicology. Boca Raton: CRC Press; 2014;343-54.

Article History: Submission Date: 19-12-16; Revision Date:07-01-17; Accepted Date:13-01-17.

Cite this article: Saputri FC, Adiyati Z, Waty DR. Nephroprotective Effect of Pterocarpus indicus Willd. Leaves: Observation of Urine Volume, Sodium and Potassium Levels in Gentamicin-induced Rat Model. J Young Pharm. 2017;9(1)Suppl:s85-s8. 